\title{
PENINGKATAN PRODUKTIFITAS LAHAN GAMBUT MELALUI TEKNIK AMELIORASI DAN INOKULASI MIKROBA PELARUT FOSFAT
}

\section{ENCHANCEMENT OF PEAT SOIL PRODUCTIVITY THROUGH AMELIORANT AND PHOSPHAT SOLUBILIZING MICROBE INOCULATION TECHNIQUE}

\author{
Ida Nur Istina ${ }^{1)}$, Benny Joy ${ }^{2)}$, dan Aisyah D Suyono ${ }^{2)}$ \\ ${ }^{1)}$ Balai Pengkajian Teknologi Pertanian Riau, Jl. Kaharudin Nst 341 Pekanbaru \\ ${ }^{2)}$ Fakultas Pertanian Universitas Padjadjaran, Jl. Raya Jatinangor Sumedang Km. 21 Sumedang \\ Korespondensi : idanuristina@gmail.com
}

Diterima 7 Oktober 2014 /Disetujui 8 Desember 2014

\begin{abstract}
ABSTRAK
Keterbatasan lahan potensial menyebabkan perluasan areal pertanian mengarah pada lahan gambut. Kendala pengembangan lahan gambut adalah rendahnya kandungan hara tersedia bagi tanaman. Fosfat (P) merupakan salah satu unsur hara makro yang penting untuk pertumbuhan dan produksi tanaman, disisi lain ketersediaan hara ini pada lahan gambut terbatas karena ikatan asam organik dan sifat yang mudah tercuci. Penelitian untuk menguji pengaruh ameliorasi dan inokulasi mikroba pelarut fosfat terhadap ketersediaan hara $\mathrm{P}$ di lahan gambut dilakukan di kebun pembibitan kelapa sawit petani di Riau dari Oktober 2013 Maret 2014, menggunakan Rancangan Acak Kelompok pola Faktorial dengan 30 kombinasi perlakuan dan 3 kali ulangan. Variabel yang diamati meliputi : tinggi tanaman, lingkar batang, jumlah daun, lebar daun, panjang daun, kandungan hara tanaman, dan bobot biomasa bibit setelah 5 bulan di pembibitan. Hasil penelitian menunjukkan bahwa ameliorasi menggunakan kompos tandan kosong kelapa sawit mampu meningkatkan $\mathrm{P}$ tersedia, serapan $\mathrm{P}$ oleh batang dan akar, berat brangkasan dan berat kering batang. Sedangkan mikroba pelarut fosfat berpengaruh secara tidak nyata.
\end{abstract}

Kata kunci : Bibit Kelapa Sawit, Fosfat, Gambut Saprik, Mikroba Pelarut Fosfat, Pertumbuhan Tanaman

\begin{abstract}
The limitation of potential land leads agricultural development expansion to the peat soil area. Constrain of the peatland development is the low nutrient content that is required by plant. Phosphate is one of major growth and production limiting nutrient because of the solublelize of the organic acids and immobility The research was conducted from October 2013 - March 2014 at the farmer main nursery in Riau province to test the effect of amelioration and phosphate solubilizing microbe inoculation on $\mathrm{P}$ availability on palm oil seedling growth and production at peatland, used Randomized Block Design with 30 treatments and 3 replications. The parameters observed were plant height, leaf number, leaf width, leaf length, stem diameters, nutrient contents, also fresh and dry weight after 5 months at the main nursery. The result showed that palm oil empty fruit bunch compost as ameliorant increased $\mathrm{P}$
\end{abstract}


nutrient avaibility, P uptake, fresh and dry weight, whereas phosphate solubilizing microbe was unsignificant.

Key words : Palm Oil Seedling, Peat Soil, Phosphate, Phosphate Solubilizing Microbe, Plant Growth

\section{PENDAHULUAN}

Lahan gambut merupakan lahan sub optimal harapan. Luas gambut di Indonesia mencapai 14,95 juta ha, 55,4\% diantaranya berpotensi untuk pengembangan komoditas pertanian termasuk kelapa sawit (Ritung et al., 2011). Kelapa sawit merupakan salah satu komoditas perkebunan andalan sumber devisa, lapangan kerja dan sumber kesejahteraan bagi petani pengusahanya. Luasan kelapa sawit tahun 2012 mencapai 7.480.750 hektar yang tersebar di seluruh wilayah Indonesia; 1.149.780 hektar diantaranya lahan gambut sebagai akibat semakin menipisnya lahan potensial (BBSDLP, 2012). Salah satu kendala pengembangan komoditas kelapa sawit di lahan gambut adalah rendahnya kandungan hara tersedia yang diperlukan tanaman untuk tumbuh dan berkembang; diantaranya adalah unsur hara fosfat.

Fosfat merupakan salah satu unsur hara makro yang penting setelah nitrogen untuk pertumbuhan dan perkembangan tanaman (Abdolzadeh et al., 2010). Pada tanaman kelapa sawit, hara $P$ diperlukan untuk pertumbuhan batang, akar, dan metabolisme tanaman yang diindikasikan oleh berat kering tanaman. Kurangnya asupan unsur $\mathrm{P}$ menyebabkan tidak normalnya pertumbuhan dan produksi tanaman (Sharma et al., 2013). Tanaman kelapa sawit akan mengalami defisiensi hara jika jumlah hara $\mathrm{P}$ di daun kurang dari 15\% (Kasno et al., 2010). Meskipun penting, namun ketersediaan unsur hara $\mathrm{P}$ di alam sangat terbatas dengan kisaran antara 0,1$0,25 \mathrm{~N}$ dan 0,05 K dalam bentuk anorganik berupa bahan tambang (Prasad dan Power, 2000). Pada tanah gambut fosfat terkhelat oleh unsur $\mathrm{Fe}$ atau $\mathrm{Al}$ dalam bentuk fosfolipida dengan kisaran antara 0,17-0,33 mg $\mathrm{g}^{-1}$ (Berg dan Mc.Claugherty, 2008) sehingga tidak tersedia, akibatnya hanya $30 \%$ diantaranya yang dapat diserap tanaman.

Salah satu upaya untuk memperbaiki status kesuburan tanah gambut adalah dengan ameliorasi yang berperanan selain menurunkan tingkat keasaman tanah (Mawardi et al., 1999) yang menjadi faktor pembatas daya adaptasi tanaman; meningkatkan status hara tanah melalui mekanisme substitusi hara khususnya $\mathrm{N}, \mathrm{P}$ dan K yang sulit diakses petani (Soewandita, 2003) dan berpengaruh positif terhadap kolonisasi dan interaksi mikroba sehingga dapat meningkatkan perannya dalam penyediaan hara bagi tanaman (Basu et al., 2011). Kompos tandan kosong kelapa sawit yang tersedia luas di Riau berpotensi sebagai amelioran yang terjangkau. Darnoko dan Ady (2006) menyebutkan kompos tandan kosong kelapa sawit mengandung : $\mathrm{P}(0,022 \%), \mathrm{K}(3,45 \%), \mathrm{Ca}$ $(0,2 \%), \operatorname{Mg}(0,54 \%), C(29,76 \%), N(1,98 \%)$, $\mathrm{C} / \mathrm{N} \quad(15,03 \%)$ dan air (54,39\%) yang berpotensi untuk mensubstitusi sebagian unsur hara yang diperlukan tanaman, dan dapat meningkatkan $\mathrm{pH}$ tanah dari 3,5-3,6 menjadi 5,5 (Nurani et al., 2011), serta meningkatkan produktifitas tanaman jagung di lahan gambut hemis $58 \%$ dibanding 
kontrol (Nurhayati et al., 2011). Selain ameliorasi, pemupukan merupakan upaya efektif untuk meningkatkan produktifitas tanaman, namun pemupukan sesuai dosis anjuran sulit dicapai petani karena kurangnya kemampuan keuangan petani dan ketersediaan pupuk yang sering tidak tepat. Hasil penelitian menunjukkan bahwa di alam mikroba baik dari jenis bakteri, fungi dan aktinomiset tersedia melimpah yang berkemampuan untuk membantu penyediaan hara bagi tanaman melalui mekanisme, penambatan, pelarutan dan mineralisasi hara $\mathrm{P}$ anorganik dan organik menjadi tersedia bagi tanaman (Khan et al., 2009 ) dan fasilitasi.

Suriadikarta dan Simanungkalit (2006), menyebutkan bahwa Bacillus subtilis, Bacterium mycoides dan B. mesentericus dapat melarutkan $\mathrm{P}$ organik $\left(\mathrm{FePO}_{4}\right), \mathrm{Ca}_{3}$ $\left(\mathrm{PO}_{4}\right)_{2}$, glicerofosfat, lesitin dan tepung tulang secara in vitro berturut-turut sebesar 2-7, 3-9, 3-13, 5-21 dan 14 persen. Selain bakteri hasil penelitian menyebutkan bahwa fungi mampu melarutkan $P$ dalam bentuk $\mathrm{AlPO}_{4}$ pada tanah masam bahkan lebih tinggi dibandingkan bakteri (Goenadi dan Saraswati, 1993) dengan kemampuan antara 12-162 ppm di medium Pikovskaya yang mengandung sumber $\mathrm{P} \quad \mathrm{AlPO}_{4}$ yang relatif lebih sukar larut sebesar $27-47 \%$ (Lestari dan Saraswati, 1997). Proses mineralisasi yang dilakukan oleh mikroba melalui mekanisme pengeluaran asam organik akan mengubah fosfat yang sukar larut menjadi tersedia bagi tanaman. Fungi yang menunjukkan kemampuannya dalam melrutkan fosfat diantaranya adalah Aspergillus sp. dan Penicillium sp. (Khan dan Khan, 2002); Rhizoctonia solani (Jacobs et al., 2002). Aplikasi fungi pelarut fosfat seperti Penicillium, Mucor dan Aspergilus mampu meiningkatkan pertumbuhan tanaman (El-Yazeid dan Abou-Aly, 2011), hingga 5-20\% (Gunes et al., 2009) dan mengurangi penggunaan pupuk (Singh dan Reddy 2011; Zaidi et al., 2009) Kemampuan mikroba pelarut fosfat di tanah gambut belum banyak diketahui, oleh karena itu dilakukan penelitian yang bertujuan untuk mengetahui pengaruh ameliorasi dan inokulasi mikroba pelarut fosfat terhadap ketersediaan hara $P$ di lahan gambut untuk pertumbuhan bibit kelapa sawit.

\section{BAHAN DAN METODE}

Penelitian dilaksanakan di kebun bibit petani dan mengikutsertakan petani sebagai koperator di Riau dari bulan Oktober 2013 Mei 2014, menggunakan Rancangan Acak Kelompok Faktorial dengan tiga kali ulangan. Faktor pertama adalah isolat (3 taraf) yaitu : $\mathrm{i}_{0}=$ tanpa isolat (kontrol), $\mathrm{i}_{1}=$ isolat bakteri Burkholderia sp., $\mathrm{i}_{2}=$ isolat Penicillium aculeatum dan faktor kedua adalah amelioran (10 taraf) terdiri dari $a_{1}=$ kompos tankos, $a_{2}=$ kontrol, $a_{3}=$ kompos tankos $+25 \% \mathrm{P}, \mathrm{a}_{4}=$ kompos tankos $+50 \% \mathrm{P}$, $a_{5}=$ kompos tankos $+75 \%, a_{6}=$ kompos tankos $+100 \% \mathrm{P}, \mathrm{a}_{7}=25 \% \mathrm{P}, \mathrm{a}_{8}=50 \% \mathrm{P}$, $a_{9}=75 \% P, a_{10}=100 \% P$.

Bahan tanaman yang digunakan adalah bibit kelapa sawit varietas AA DP TOPAS 3 umur 4 bulan setelah semai. Inokulan mikroba pelarut fosfat adalah mikroba yang terindikasi sebagai mikroba pelarut fosfat yang diisolasi dari tanah gambut saprik Riau menggunakan media selektif Pikovskaya.

Media tanam yang digunakan adalah tanah gambut dangkal asal kabupaten Pelalawan yang diambil pada kedalaman 0$20 \mathrm{~cm}$; dikeringanginkan dan disaring dengan diameter saringan $2 \mathrm{~mm}$, tanah kemudian dicampur dengan kompos tankos 
dengan perbandingan 1:1 sesuai perlakuan dan dimasukkan ke dalam polibag ukuran $40 \mathrm{~cm} \times 50 \mathrm{~cm}$.

\section{Penyiapan Inokulan}

Inokulum diperbanyak dengan menambahkan $10 \mathrm{ml} \mathrm{NaCl}$ fisiologis (0,85\%) pada stok isolat murni pada permukaan agar miring sehingga menjadi suspensi mikroba yang kemudian diinkubasikan pada suhu $30^{\circ} \mathrm{C}$ hingga mencapai fase eksponensial yang dipercepat. Sebanyak $10 \%$ suspensi dikulturkan dalam $100 \mathrm{ml}$ medium yang mengandung $10 \mathrm{mM}$ asam fitat pada suhu kamar. Pada akhir inkubasi, konsentrasi sel mikroba dihitung kepadatannya.

Tabel 1. Sifat tanah yang digunakan dalam penelitian

\begin{tabular}{|c|c|c|}
\hline Kandungan & Nilai & Satuan \\
\hline $\mathrm{pH}$ & 3 & \\
\hline $\mathrm{C}$ & 37,35 & \\
\hline N (\%) & 1,83 & \\
\hline $\mathrm{C} / \mathrm{N}$ & 20 & \\
\hline $\mathrm{P}_{2} \mathrm{O}_{5}$ (P-Bray I) & 22,8 & $\mathrm{ppm}$ \\
\hline K MV (ppm) & 175,4 & ppm \\
\hline $\mathrm{P}_{2} \mathrm{O}_{5}(\mathrm{HCl} 25 \%)$ & 59,22 & $\mathrm{mg} 100 \mathrm{~g}^{-1}$ \\
\hline $\mathrm{K}_{2} \mathrm{O}(\mathrm{HCl} 25 \%)$ & 42,84 & $\mathrm{mg} 100 \mathrm{~g}^{-1}$ \\
\hline $\mathrm{Mg}$ & 3,05 & $\mathrm{cmol} \mathrm{kg}^{-1}$ \\
\hline
\end{tabular}

Sumber: Laboratorium Tanah Balitsa lembang, 2013

\section{Penanaman}

Masing-masing bibit kelapa sawit umur 4 bulan ditanam pada polibag berisi media yang telah disiram hingga jenuh dan diberi lubang tanam dengan diameter $14 \mathrm{~cm}$. Sebelum bibit ditanam ke dalam lubang tanam diberikan pupuk dasar $0,569 \mathrm{~g} \mathrm{~N}^{-} \tan ^{-}$ ${ }^{1}+0,458 \mathrm{~g} \mathrm{P} \tan ^{-1}+0,276 \mathrm{Ktan}^{-1}+0,201 \mathrm{~g}$ $\mathrm{Mg} \tan ^{-1}$.

\section{Pemupukan}

Pemupukan bibit dilakukan dua minggu setelah tanam pindah menggunakan pupuk tunggal secara tabur dan dibenamkan. Pupuk $\mathrm{N}$ diberikan dalam bentuk Urea, $\mathrm{P}$ diberikan dalam bentuk TSP, $K$ dalam bentuk $\mathrm{KCl}$ dan $\mathrm{Mg}$ dalam bentuk kiserit, sesuai dengan perlakuan sebagaimana tertera pada Tabel 2.

Inokulan diinokulasikan pada sore hari dengan tingkat kerapatan $10^{9}$ sebanyak 15 $\mathrm{ml}$ per tanaman dengan menuangkan larutan ke dalam tanah sesuai dosis perlakuan. Pemeliharaan meliputi penyiangan terhadap gulma yang tumbuh serta penyemprotan pestisida untuk mencegah serangan hama dan penyakit tanaman.

Tabel 2. Dosis pupuk dan waktu pemupukan

\begin{tabular}{ccccccccc}
\hline \multirow{2}{*}{$\begin{array}{c}\text { Minggu } \\
\text { ke- }\end{array}$} & $\mathrm{N}$ & \multicolumn{7}{c}{ Dosis Pupuk $\left(\mathrm{g} \mathrm{tan}^{-1}\right)$} \\
\cline { 2 - 7 } & & $100 \%$ & $75 \%$ & $50 \%$ & $25 \%$ & Kontrol & & $\mathrm{Mg}$ \\
\hline 18 & 1,594 & 1,283 & 0,963 & 0,642 & 0,321 & 0 & 0,774 & 0,563 \\
20 & 2,278 & 1,833 & 1,375 & 0,917 & 0,458 & 0 & 1,106 & 0,804 \\
22 & 2,278 & 1,833 & 1,375 & 0,917 & 0,458 & 0 & 1,106 & 0,804 \\
24 & 2,278 & 1,833 & 1,375 & 0,917 & 0,458 & 0 & 1,106 & 0,804 \\
26 & 3,644 & 2,933 & 2,200 & 1,467 & 0,733 & 0 & 6,271 & 7,638 \\
28 & 3,644 & 2,933 & 2,200 & 1,467 & 0,733 & 0 & 6,271 & 7,638 \\
30 & 3,644 & 2,933 & 2,200 & 1,467 & 0,733 & 0 & 6,271 & 7,638 \\
32 & 4,556 & 3,667 & 2,750 & 1,833 & 0,917 & 0 & 7,839 & 8,040 \\
34 & 4,556 & 3,667 & 2,750 & 1,833 & 0,917 & 0 & 7,839 & 8,040 \\
35 & 4,556 & 3,667 & 2,750 & 1,833 & 0,917 & 0 & 7,839 & 8,040 \\
\hline
\end{tabular}




\begin{abstract}
Variabel yang diamati meliputi: pertumbuhan tinggi tanaman 5 bulan setelah tanam, jumlah daun, lingkar batang, bobot basah dan kering batang dan akar, serapan hara $\mathrm{P}$ dalam akar dan batang. Pada 20 minggu setelah perlakuan, tanaman dicabut dengan hati-hati, dibersihkan dari tanah dan dicuci agar tanah yang menempel pada akar terlepas kemudian ditimbang bobot akar, batang dan daun serta analisis kandungan hara $P$ untuk menentukan serapan hara $\mathrm{P}$ oleh bibit kelapa sawit. Data yang terkumpul ditabulasikan dan dianalisis menggunakan perangkat lunak SPSS versi 16.
\end{abstract}

\section{HASIL DAN PEMBAHASAN}

\section{Keragaan Status Hara Tanah}

Hasil analisis tanah sebelum perlakuan mengindikasikan bahwa gambut yang digunakan sebagai media tanam meskipun sudah merupakan gambut matang, namun memiliki tingkat keasaman tinggi, dengan status hara $\mathrm{N}$ rendah, $\mathrm{P}$ sedang dan $\mathrm{K}$ tinggi.

Pada tanah gambut kemasaman dan rendahnya kandungan hara tersedia bagi tanaman merupakan sifat tanah yang perlu mendapatkan perhatian untuk tujuan produktifitas pertanian. Upaya yang dilakukan untuk meningkatkan $\mathrm{pH}$ tanah adalah dengan melakukan kegiatan ameliorasi sedangkan kesuburan lahan disikapi dengan pemupukan. Hasil analisis statistik terhadap parameter tingkat kemasaman tanah menunjukkan bahwa tidak terjadi interaksi antara aplikasi amelioran kompos tandan kosong kelapa sawit dan inokulasi mikroba pelarut fosfat namun secara mandiri amelioran tandan kosong kelapa sawit menunjukkan perbedaan yang nyata (Tabel 3 ).

Tabel 3. Keragaan $\mathrm{pH}$ tanah setelah perlakuan

\begin{tabular}{|c|c|c|}
\hline Perlakuan & $\mathrm{pH}$ Tana & \\
\hline Kompos tankos & 4,4 & $a b$ \\
\hline Kontrol & 4,3 & $a b$ \\
\hline Kompos tankos $+25 \% \mathrm{P}$ & 4,7 & $b$ \\
\hline Kompos tankos $+50 \% \mathrm{P}$ & 4,7 & $b$ \\
\hline Kompos tankos $+75 \% \mathrm{P}$ & 4,3 & $a b$ \\
\hline Kompos tankos $+100 \% \mathrm{P}$ & 4,4 & $a b$ \\
\hline $25 \% P$ & 4,6 & $b$ \\
\hline $50 \% \mathrm{P}$ & 4,3 & $a b$ \\
\hline $75 \%$ P & 4,2 & a \\
\hline $100 \% P$ & 4,5 & $a b$ \\
\hline Kontrol & 4.51 & a \\
\hline Burkholderia gladioli & 4,35 & a \\
\hline Penicillium aculeatum & 4,44 & a \\
\hline
\end{tabular}

Keterangan : Angka yang diikuti huruf yang sama tidak berbeda nyata pada taraf beda nyata $5 \%$ menurut Uji Jarak Berganda Duncan.

Kenaikan derajat keasaman $(\mathrm{pH})$ media yang diberi amelioran $+25 \%$ pupuk $\mathrm{P},+$
$50 \% \mathrm{P}$ dan Gambut $+25 \% \mathrm{P}$ berbeda nyata dengan media gambut tanpa amelioran + 
$75 \% \mathrm{P}$, meskipun sesama perlakuan amelioran tidak berbeda nyata. Penambahan kompos tandan kosong kelapa sawit menyebabkan terjadinya peningkatan muatan negatif pada permukaan koloid tanah yang menyebabkan $\mathrm{pH}$ meningkat (Amirrudin, 2008). Hal ini sesuai dengan pendapat Hartatik (2012) bahwa amelioran dapat meningkatkan $\mathrm{pH}$ tanah, sementara Mawardi et al., (1999) menyatakan bahwa amelioran dapat memperbaiki stabilitas tanah dan menurunkan konsentrasi asam fenolat. Lebih lanjut Nurani et al. (2011), dari hasil penelitiannya menyatakan bahwa penggunaan tandan kosong kelapa sebagai amelioran meningkatkan $\mathrm{pH}$ tanah gambut dari 3,6 menjadi 5,5.

Keragaan $\mathrm{pH}$ tanah gambut $+75 \% \mathrm{P}$ menunjukkan nilai paling rendah, hal ini dikarenakan kegiatan pemupukan meningkatkan keasaman tanah karena terlepasnya ion $\mathrm{H}^{+}$, disisi lain aktivitas mikroba menghasilkan asam organik juga memicu peningkatan derajat keasaman tanah. Kenaikan $\mathrm{pH}$ berdampak pada keragaman mikroba potensial dan ketersediaan hara bagi tanaman dalam tanah. Sharma et al. (2011) serta Paul dan Sinha, (2013) menyebutkan bahwa mekanisme pelarutan fosfat oleh mikroba pelarut fosfat dengan menghasilkan asam organik dan enzim fosfatase menyebabkan penurunkan $\mathrm{pH}$ tanah.

Hasil analisis kandungan hara tanah menunjukkan bahwa ameliorasi dan inokulasi MPF dan pemupukan mempengaruhi kandungan hara tanah khususnya fosfat (Tabel 4). Artinya pemberian amelioran dapat memperbaiki kondisi tanah sehingga meningkatkan ketersediaan hara. Darnoko dan Ardy, (2006) menyebutkan bahwa kompos tandan kososng kelapa sawit memiliki sifat yang baik antara lain memperbaiki struktur tanah; membantu kelarutan hara yang diperlukan tanaman dan merupakan pupuk yang tidak mudah tercuci. Lebih lanjut disebutkan bahwa kompos tandan kosong kelapa sawit memiliki kandungan hara $\mathrm{N}$ (2-3\%), P (0,2-0,4\%), K (4-6\%, Ca (1-2\%) dan Mg (0,8-1\%). Inokulasi MPF pada tanah gambut $+25 \% \mathrm{P}$ memberikan keragaan kandungan hara $\mathrm{N}, \mathrm{K}, \mathrm{Ca}, \mathrm{Mg}$ tertinggi, meskipun kandungan $\mathrm{P}$ tertinggi terdapat pada tanah gambut $+100 \% \mathrm{P}$ dan kandungan Al terendah. Inokulasi mikroba pelarut fosfat pada tanah gambut tanpa ameloran membantu ketersediaan hara.

Mikroba pelarut fosfat berperanan dalam melarutkan fosfat yang terikat oleh asam organik dan menjaga unsur $P$ yang terlarut tidak hilang dan terikat oleh asam organik tanah sehingga dapat tersedia bagi tanaman. Mikroba pelarut fosfat baik bakteri maupun fungi menghasilkan asam organik monokarboksilat seperti asam asetat, asam formiat, monokarboksil hidroksil seperti asam laktat, asam monokarboksil ketogluconat (asam oksalat, suksinat dan dikarboksilat hiroksilat sperti asam malat untuk melarutkan $\mathrm{P}$ (Khan et al., 2009). Selain itu fosfat juga dapat dilarutkan oleh enzim yang dihasilkan mikroba (Jinhee et al., 2010). Lebih lanjut disebutkan bahwa spesies fungi seperti Aspergillus, dan Penicillium serta bakteri seperti Bacillus, Rhizobium, Burkholderia, Achromobacter, Agrobacterium, Micrococcus, Aerobacter, Flavobacterium dan Erwinia berkemampuan sebagai pelarut fosfat. 
Tabel 4. Kandungan hara media tanam setelah perlakuan

\begin{tabular}{|c|c|c|c|c|c|c|c|c|}
\hline \multirow{2}{*}{ Perlakuan } & \multicolumn{8}{|c|}{ Kandungan Hara } \\
\hline & $\mathrm{C}$ & $\mathrm{N}$ & $\mathrm{C} / \mathrm{N}$ & $P$ & $\mathrm{~K}$ & $\mathrm{Ca}$ & Mg & $\mathrm{Al}$ \\
\hline Kompos tankos & 28,64 & 2,52 & 11,33 & 1568,94 & 6505,03 & 27,16 & 40,48 & 67,03 \\
\hline Kontrol & 27,87 & 2,62 & 10,67 & 1517,84 & 6747,87 & 27,45 & 42,19 & 48,93 \\
\hline Kompos tankos $+25 \% \mathrm{P}$ & 28,44 & 2,75 & 10,00 & 1798,92 & 6107,87 & 32,00 & 40,90 & 30,43 \\
\hline Kompos tankos $+50 \% \mathrm{P}$ & 28,68 & 2,52 & 11,33 & 2113,33 & 6532,13 & 34,67 & 45,41 & 17,10 \\
\hline Kompos tankos $+75 \% \mathrm{P}$ & 28,26 & 2,69 & 10,67 & 2993,67 & 6472,63 & 28,42 & 40,77 & 9,27 \\
\hline Kompos tankos $+100 \% \mathrm{P}$ & 29,19 & 2,70 & 10,67 & 3056,09 & 5270,70 & 27,74 & 34,47 & 20,20 \\
\hline $25 \% \mathrm{P}$ & 30,14 & 2,76 & 11,00 & 1938,04 & 7008,00 & 36,37 & 48,20 & 16,63 \\
\hline $50 \% \mathrm{P}$ & 29,00 & 2,84 & 10,33 & 2832,29 & 6086,53 & 26,81 & 3,69 & 5,80 \\
\hline $75 \% \mathrm{P}$ & 29,99 & 2,93 & 10,33 & 3174,04 & 5300,73 & 20,27 & 2,88 & 9,13 \\
\hline $100 \% \mathrm{P}$ & 30,22 & 2,69 & 11,00 & 3635,27 & 5921,40 & 24,83 & 3,57 & 3,57 \\
\hline
\end{tabular}

Sumber : Laboratorium Tanah Balitsa Lembang, 2013

\section{Keragaan Pertumbuhan Tanaman}

Hasil analisis statistika menunjukkan bahwa ameliorasi dan inokulasi mikroba pelarut fosfat tidak menunjukkan perbedaan yang nyata antar perlakuan terhadap pertumbuhan bibit kelapa sawit (tinggi tanaman, jumlah daun, dan lingkar batang (Tabel 5). Hal ini kemungkinan disebabkan kebutuhan hara untuk pertumbuhan optimal masih dapat dipenuhi oleh media gambut.

Tabel 5. Keragaan rata-rata pertumbuhan bibit kelapa sawit

\begin{tabular}{lccc}
\hline \multicolumn{1}{c}{ Perlakuan } & $\begin{array}{c}\text { Tinggi Tanaman } \\
(\mathrm{cm})\end{array}$ & $\begin{array}{c}\sum \text { Daun } \\
(\mathrm{lbr})\end{array}$ & $\begin{array}{c}\text { Diameter } \\
\text { Batang }(\mathrm{cm})\end{array}$ \\
\hline Kompos tankos & 72,57 & 10,50 & 4,61 \\
Kontrol/tanpa amelioran & 70,72 & 10,47 & 4,83 \\
Kompos tankos + 25\% P & 72,86 & 10,64 & 4,51 \\
Kompos tankos + 50\% P & 73,40 & 10,53 & 4,67 \\
Kompos tankos + 75\% P & 71,38 & 10,36 & 4,53 \\
Kompos tankos + 100\% P & 71,74 & 10,92 & 4,48 \\
$25 \%$ P & 73,54 & 11,22 & 4,45 \\
$50 \%$ P & 73,07 & 10,64 & 4,56 \\
$75 \%$ P & 73,74 & 10,44 & 4,45 \\
$100 \%$ P & 72,24 & 10,47 & 4,44 \\
& & & \\
Burkholderia gladioli & 71,92 & 78,95 & 4,51 \\
Penicillium aculeatum & 72,97 & 81,93 & 4,66 \\
\hline
\end{tabular}

Keterangan : Angka yang diikuti huruf yang sama menunjukkan tidak berbeda nyata pada taraf beda nyata $5 \%$

Pertumbuhan vegetatif tanaman dipengaruhi oleh banyak faktor termasuk diantaranya kecukupan hara seperti unsur hara $\mathrm{N}$ sebagai penyusun sel yang merangsang pertumbuhan vegetatif yaitu tinggi tanaman sedangkan unsur $P$ berperan dalam pembelahan sel untuk membentuk organ tanaman. Bibit kelapa sawit akan mengalami defisiensi yang menyebabkan pertumbuhan tanaman tidak normal jika kandungan hara $\mathrm{P}$ dalam tanah kurang dari $15 \mathrm{mg} \mathrm{P} \mathrm{kg}^{-1}, \mathrm{~K}$ kurang 
dari $0,15 \mathrm{cmol} \mathrm{kg}^{-1}$. Tinggi tanaman tertinggi terdapat pada perlakuan inokulasi MPF pada Gambut $+75 \%$ P $(73,74 \mathrm{~cm})$ dan terendah pada inokulasi MPF pada media gambut $(70,72 \mathrm{~cm})$. Artinya bahwa bahwa inokulasi MPF meningkatkan pertumbuhan bibit kelapa sawit jika dikombinasikan dengan bahan anorganik.

Pertambahan jumlah daun terbanyak terdapat pada perlakuan inokulasi MPF pada gambut $+25 \%$ P $(11,25$ lembar $)$ dan terendah pada inokulasi MPF pada iokulasi MPF pada media gambut + Kompos tankos $+75 \%$ P (10,36 lembar). Pembentukan organ baru ditentukan oleh unsur hara $\mathrm{P}$. Hasil penelitian ini menunjukkan bahwa MPF bekerja dengan baik pada tanah yang kandungan hara $P$ nya rendah. Pada kondisi hara $\mathrm{P}$ tersedia MPF tidak bekerja. Gambut memiliki kandungan $P$ tinggi tetapi tidak tersedia bagi tanaman sehingga inokulasi MPF memicu MPF melakukan aktivitas pelarutan dengan baik. Peranan MPF adalah menguraikan unsur hara $\mathrm{P}$ dan mencegah $\mathrm{P}$ yang terurai terkhelat oleh koloid tanah sehingga pertumbuhan tanaman menjadi lebih baik.

Pertambahan diameter batang terbesar terdapat pada perlakuan inokulasi MPF pada tanah gambut $(4,83 \mathrm{~cm})$ dan terkecil pada perlakuan inokulasi MPF pada Gambut $+100 \% \quad P$ artinya bahwa penambahan $\mathrm{P}$ menghambat aktifitas MPF untuk melakukan aktifitas pelarutan hara $P$, sementara dari $100 \% \quad P$ yang diaplikasikan $80 \%-90 \%$ difiksasi komponen tanah sehingga tidak tersedia bagi tanaman.

Secara terpisah menunjukkan bahwa inokulan Penicillium aculeatum meskipun tidak nyata memberikan pertumbuhan vegetatif tanaman yang lebih baik dibandingkan inokulan bakteri Burkholderia gladioli. Hal ini kemungkinan diakibatkan oleh kemampuan adaptasi fungi pada lahan masam lebih baik. Pada umumnya bakteri lebih sesuai dengan kondisi basa.

\section{Berat Biomassa Bibit Kelapa Sawit}

Aplikasi MPF pada berbagai media menunjukkan perbedaan yang nyata. Berat brangkasan bibit kelapa sawit tertinggi pada media gambut $+75 \% \mathrm{P}$, Gambut + $100 \%$ P, Gambut + tankos $+100 \%$ P dan Gambut + tankos tetapi tidak berbeda nyata dengan aplikasi MPF pada media Gambut + tankos + 50\% P, Gambut + 75\% $P$, Gambut $+50 \%$ P namun berbeda nyata dengan aplikasi MPF pada tanah gambut, demikian juga pada berat brangkasan akar (Tabel 6) Hal ini menunjukkan bahwa berat biomasa tanaman ditentukan oleh penambahan bahan anorganik baik dalam bentuk pupuk kimia yang ditambahkan maupun yang berasal dari kompos tandan kosong kelapa sawit yang merupakan bahan baku untuk proses fotosintesa dan proses metabolisme tanaman lainnya. Hasil dari proses tersebut pada akhirnya didistribusikan kembali pada seluruh bagian tanaman. Hasil penelitian juga menunjukkan bahwa MPF berkontribusi dalam penyediaan hara $P$ melalui mekanisme penguraian unsur $\mathrm{P}$ dari $\mathrm{P}$ anorganik dan mencegah khelasi oleh asam organik gambut. Unsur hara $P$ diperlukan tanaman untuk pertumbuhan akar, proses fotosintesis dan metabolisme lainnya. Selain itu inokulasi mikroba pelarut fosfat akan meningkatkan lapisan yang sesuai untuk pertumbuhan dan produksi tanaman serta kelestarian kesehatan tanah (Sharma, 2011).

Hasil analisis statistika menunjukkan bahwa aplikasi MPF secara tunggal tidak berpengaruh nyata terhadap keragaan berat kering batang (bagian atas tanaman), 
namun pengaruhnya menjadi nyata pada berbagai media dengan kombinasi kompos tankos dan pupuk $P$ anorganik, meski tidak berbeda nyata pada bagian akar tanaman.

Hal ini berarti bahwa hara didistribusikan secara merata baik pada bagian atas tanaman maupun bagian bawah tanaman (akar). Berat brangkasan tertinggi terdapat pada perlakuan gambut + 75\% $\mathrm{P}$ yang tidak berbeda nyata dengan semua perlakuan lain kecuali perlakuan control, hal ini menunjukkan bahwa kecukupan hara $P$ yang diperlukan tanaman untuk proses metabolisme yang diindikasikan dengan berat brangkasan berasal dari $\mathrm{P}$ yang diberikan dan kandungan $\mathrm{P}$ asal tandan kosong kelapa sawit. Selain itu ameliorasi berpengaruh pada peningkatan $\mathrm{pH}$ tanah yang berdampak baik pada ketersediaan hara $\mathrm{P}$ bagi tanaman. Pada gambut yang tidak terameliorasi kecukupan hara $P$ selain dipengaruhi oleh $\mathrm{P}$ yang diberikan juga dipengaruhi oleh adanya mikroba pelarut fosfat yang berperanan dalam mencegah $P$ terlarut diikat oleh aluminium tanah sehingga tersedia bagi tanaman yang diindikasikan dengan pertambahan bobot biomassa (Panhwar et al., 2013).

Tabel 6. Keragaan berat brangkasan dan berat kering tanaman

\begin{tabular}{|c|c|c|c|c|c|c|c|c|}
\hline \multirow{3}{*}{$\begin{array}{l}\text { Perlakuan } \\
\text { Kompos tankos }\end{array}$} & \multicolumn{4}{|c|}{ Brangkasan (g) } & \multicolumn{4}{|c|}{ Berat Kering (g) } \\
\hline & \multicolumn{2}{|c|}{ Batang } & \multicolumn{2}{|c|}{ Akar } & \multicolumn{2}{|c|}{ Batang } & \multicolumn{2}{|l|}{ Akar } \\
\hline & 321,99 & $b$ & 100,61 & $a b$ & 104,79 & bc & 21,64 & $a$ \\
\hline Kontrol/tanpa amelioran & 250,28 & a & 82,99 & $a$ & 84,69 & $a b$ & 18,76 & $\mathrm{a}$ \\
\hline Kompos tankos $+25 \% \mathrm{P}$ & 279,60 & $a b$ & 89,77 & $a b$ & 90,19 & $a b c$ & 20,63 & $\mathrm{a}$ \\
\hline Kompos tankos $+50 \% \mathrm{P}$ & 302,70 & $a b$ & 103,97 & $a b$ & 97,79 & $a b c$ & 21,75 & a \\
\hline Kompos tankos $+75 \% \mathrm{P}$ & 281,30 & $a b$ & 101,89 & $a b$ & 83,61 & $a$ & 18,97 & a \\
\hline Kompos tankos $+100 \% \mathrm{P}$ & 339,71 & $b$ & 108,80 & $b$ & 106,23 & c & 23,30 & $\mathrm{a}$ \\
\hline $25 \% \mathrm{P}$ & 290,17 & $a b$ & 104,79 & $a b$ & 90,41 & $a b c$ & 19,97 & a \\
\hline $50 \% \mathrm{P}$ & 289,26 & $a b$ & 107,54 & $b$ & 90,71 & $a b c$ & 19,13 & $\mathrm{a}$ \\
\hline $75 \% \mathrm{P}$ & 348,62 & $b$ & 108,92 & $b$ & 103,46 & $a b c$ & 20,15 & a \\
\hline $100 \% \mathrm{P}$ & 322,18 & $b$ & 113,10 & $b$ & 97,77 & $a b c$ & 21,00 & a \\
\hline Burkholderia gladioli & 295 & a & 102 & a & 92 & a & 21 & $\mathrm{a}$ \\
\hline Penicillium aculeatum & 313 & $\mathrm{a}$ & 106 & $\mathrm{a}$ & 100 & a & 21 & $\mathrm{a}$ \\
\hline
\end{tabular}

Keterangan : Angka yang diikuti huruf yang sama menunjukkan tidak berbeda nyata pada taraf beda nyata $5 \%$ 


\section{Serapan Hara $\mathbf{P}$}

Hasil analisis statistika menunjukkan bahwa amelioran tankos berpengaruh nyata terhadap serapan hara, kandungan $\mathrm{P}$ di tanaman dan di tanah. Inokulasi MPF pada tanah gambut $+75 \%$ $\mathrm{P}$ memberikan keragaan serapan $\mathrm{P}$ bagian atas tanaman tertinggi $(476,23 \mathrm{mg})$ berbeda dengan perlakuan lainnya, meski tidak berbeda nyata dengan Inokulasi MPF pada tanah gambut + $100 \%$ P, dan Inokulasi MPF pada tanah gambut + tankos $+100 \% P$.

Tingginya serapan $\mathrm{P}$ pada bagian atas belum tentu seiring dengan serapan $P$ pada bagian akar. Hasil analisis statistika menunjukkan bahwa serapan unsur hara $\mathrm{P}$ oleh bagian akar terbesar terdapat pada perlakuan inokulasi MPF pada tanah gambut + kompos tankos $+100 \% \mathrm{P}$, meskipun tidak berbeda nyata dengan perlakuan inokulasi MPF pada tanah gambut + $100 \% \mathrm{P}$, inokulasi MPF pada tanah gambut + 75\% P dan inokulasi MPF pada tanah gambut + kompos tankos $+75 \%$ P. Hal ini kemungkinan jumlah unsur $P$ anorganik yang diaplikasikan cukup besar sedangkan kebutuhan tanaman masih belum maksimal. Selain itu Vessey dan Heisinger (2001) serta Fankem et al., (2006) menyebutkan bahwa tingginya serapan hara dapat diakibatkan oleh pertumbuhan dan perpanjangan akar oleh aktivitas mikroba secara tidak langsung. Schoebit et al., (2013) menyebutkan bahwa P fluorescent meningkatkan serapan $\mathrm{P}$ hingga $64 \%$ pada tanaman gandum.

Tabel 7. Keragaan serapan hara $\mathrm{P}$ pada bibit kelapa sawit 20 minggu setelah perlakuan

\begin{tabular}{lcccc}
\hline \multirow{2}{*}{ Perlakuan } & \multicolumn{4}{c}{ Serapan P $(\mathrm{mg})$} \\
\cline { 2 - 5 } & \multicolumn{3}{c}{ Batang } & \multicolumn{2}{c}{ Akar } \\
\hline Kompos tankos & 404,51 & abc & 71,88 & ab \\
Kontrol/tanpa amelioran & 307,34 & abc & 59,84 & ab \\
Kompos tankos + 25\% P & 378,42 & abc & 78,50 & ab \\
Kompos tankos + 50\% P & 405,44 & abc & 75,56 & ab \\
Kompos tankos + 75\% P & 416,97 & abc & 81,36 & abc \\
Kompos tankos + 100\% P & 436,91 & bc & 100,23 & c \\
$25 \%$ P & 352,10 & abc & 68,26 & ab \\
$50 \%$ P & 383,42 & abc & 74,42 & ab \\
$75 \%$ P & 476,23 & $c$ & 84,68 & bc \\
$100 \%$ P & 457,92 & bc & 89,57 & bc \\
\hline
\end{tabular}

Keterangan : Angka yang diikuti huruf yang sama menunjukkan tidak berbeda nyata pada taraf beda nyata $5 \%$ menurut Uji Jarak Berganda Duncan

\section{SIMPULAN}

Ameliorasi menggunakan kompos tandan kosong kelapa sawit pada tanah gambut meningkatkan $\mathrm{P}$ tersedia, serapan $\mathrm{P}$ oleh batang dan akar, berat biomassa dan berat kering batang. Selanjutnya ternyata bahwa Inokulasi MPF tidak berpengaruh nyata terhadap peningkatan $\mathrm{P}$ tersedia, serapan hara $\mathrm{P}$, berat brangkasan, berat kering dan lingkar batang bibit kelapa sawit.

\section{DAFTAR PUSTAKA}

Abdolzadeh, A., Xing Wang, Erik J. Veneklaa, dan Hans Lambers. 2010. Effect of Phosphorus Supply on Growth, Phosphate 
Concentration and Cluster-Root Formation in Three Lupinus species. Ann. Bot. Vol .105 (3), pp. 365-374.

Amirrudin. 2008. Pemberian Pupuk Fosfat, Kapur Karbonat, dan Kompos Tandan Kosong pada Typic Kandiudult untuk Meningkatkan Kadar $P$ tersedia dan Menurunkan Nilai pH. USUe-Repository.

Basu, M., P.B.S. Bhadoria, dan Mahapatra. 2011. Influence of Soil Ameliorants, Manures and Fertilizers on Bacterial Populations, Enzyme Activities, N Fixation and $\mathrm{P}$ Solubilization in Peanut Rhizosphere under Lateritic Soil. British Microbiology Research Journal 1 (1) page 11-26.

BB Litbang SDLP (Balai Besar Penelitian dan Pengembangan Sumberdaya Lahan Pertanian). 2012. Dilema dan Rasionalisasi Kebijakan Pemanfaatan Lahan Gambut untuk Areal Pertanian. Makalah Seminar Nasional Pengelolaan Lahan Gambut Berkelanjutan, Balai Besar Sumberdaya Lahan Pertanian Bogor, Mei 2012.

Berg Bjorn dan Charles Mc.Claugherty. 2008. Plant Litter. Decomposition, Humus Formation, Carbon Sequestration. Springer, Verlag Berlin Heisenberg. Second Edition, $295 \mathrm{p}$.

Darnoko dan Ady S.S. 2006. Pabrik Kompos di Pabrik Kelapa Sawit. Tabloid Sinar Tani, 9 Agustus $2006 . \quad$ Melalui http://www.litbang.deptan.go.id. [4-52012].

El-Yazeid dan H.E. Abou-Aly. 2011. Enhanching Growth, Productivity and Qualit of Tomato Plants Using Phosphat Solubilizing
Microorganisms. Australian Journal of Basic and Applied Sciences, 5(7):371-379.

Fankem, H.D. Nwaga, A. Deubel, L. Dieng, W. Merbach, dan F.X. Etoa. 2006. Occurence and Functioning of Phosphate Solubilizing Microorganisms From Oil Palm Tree (Elaeis guineensis) Rhizosphere in Cameroon. African J. Biotech.5.2450-2460.

Goenadi, D.H. dan R. Saraswati. 1993. Kemampuan Melarutkan Fosfat dari Beberapa Isolat Fungi Pelarut Fosfat. Menara Perkebunan 61 (3): 61-66.

Gunes A, Ataoglu N, Turan M, Esitken A, dan Ketterings QM. 2009. Effects of PhosphateSolubilizing Microorganisms on Strawberry Yield and Nutrient Concentrations. J. Plant Nutr. Soil Sci. 172:385-392 Publisher Full Text.

Hartatik, W. 2012. Distribusi Bentuk-bentuk Fe dan Kelarutan Amelioran Tanah Mineral dalam Gambut. Makalah Seminar Nasional Pengelolaan Lahan Gambut Berkelanjutan, Balai Besar Sumberdaya Lahan Pertanian Bogor, Mei 2012.

Jacobs H, Boswell GP, Ritz K, Davidson FA, dan Gadd GM. 2002. Solubilization of Calcium Phosphate as A Consequence of Carbon Translocation by Rhizoctonia solani. FEMS Microbiol Ecol 40:65-71.

Kasno A., Sudirman, dan M.T. Sutriadi. 2010. Efektifitas Beberapa Deposit Alam Indonesia Sebagai Pupuk Sumber Fosfor terhadap Pertumbuhan Bibit Kelapa Sawit pada Tanah Ultisol. Jurnal Litri 16 (4), hal. 165-171. 
Khan, M.R. dan Khan S.M. 2002. Effect of Rootdip Treatment with Certain Phosphate Solubilizing Microorganisms. Bioresour Technol 85(2):213-215.

Khan, A.A., Ghulam Jilani, Mohammad Saleem Akhtar, Syed Muhammad Saqlan Naqvi, dan Mohammad Rasheed. 2009. Phosphorus Solubilizing Bacteria: Occurrence, Mechanisms and their Role in Crop Production. Journal of Agricultural Biological science. 11:48-58.

Khan M.S., Zaidi A., dan Wani P.A. 2009. Role of Phosphate Solubilising Microorganisms in Sustainable Agriculture. In: Lictfouse E (ed) Sustainable Agriculture, Springer. p 552

Lestari, Y. dan R. Saraswati. 1997. Aktivitas Enzim Fosfatase Jamur Pelarut Fosfat Pada Tanah Podzolik Merah Kuning. Dalam Prosiding Seminar Pembangunan Pertanian Berkelanjutan Menyongsong Era Globalisasi, Banjarmasin 13-14 Maret 1997.

Mawardi, E., Syafei, dan A. Thaher. 1999. Pemanfaatan Kaptan Super Fosfate (KSP) dalam Paket Tampurin untuk Meningkatkan Produktivitas Kubah Gambut. BPTP Sukarami.

Nurani D., Sih Parmiyatni, Heru Purwanta, Gatot Angkoso, dan Koesnandar. 2011. Increase in $\mathrm{pH}$ of Peat Soil by Microbial Treatment. www.geog.le.ac.uk/carbopeat/media/.../p3 3.pdf. [5-4-2012].

Nurhayati, Ali Jamil, Ida Nur Istina, Yunizar, dan Hery Widyanto. 2011. Pengelolaan Lahan Gambut Berkelanjutan : Pengembangan Kelapa Sawit dan Tanaman Sela di Provinsi Riau. Makalah Seminar Nasional Pengelolaan Lahan Gambut Berkelanjutan,
Balai Besar Sumberdaya Lahan Pertanian Bogor, Mei 2012.

Panhwar, Q.A., Shamshuddin Jusop, Umme Aminun Naher, Radzih Othman, dan Mohd Ismail Razi. 2013. Application of Potential Phosphate-Solubilizing Bacteria and Organic Acids on Phosphate Solubilization from Phosphate Rock in Aerobic Rice. The Scientific World Journal. Vol 2014. Article ID 272409, $10 \quad$ pages. www.hindawi.com/journals/tswj/2013/272 409/

Park Jinhee, Nanthi Bolan, Mallavarapu Megharaj, dan Ravi Naidu. 2010. Isolation of phosphate-Solubilizing Bacteria and their Effects Characterization of on Lead Immobilization. Pedologist. 67-75.

Paul Dipak dan Sankar Narayan Sinha. 2013. Phosphate Solubilizing Activity of Some Bacterial Strain Isolated from Jute Effluent Exposed Water of River Ganga. Indian Journal of Fundamental and Applied Life Sciences. An Online Intrnational Journal Available at http://www.cibtech.org/jls.htm. 2013 Vol.3 (3) July-September, pp. 39-45.

Prasad R. dan James F. Power. 2000. Soil Fertility Management for Sustainable Agriculture. Lewis Publisher, Boca Ratoon, New York. 346 p.

Ritung, W., K.Nugroho, Sukarman, Hikmatullah, Suparo, dan C.Tafakresnanto. 2011. Peta Lahan Gambut Indonesia Skala 1 : 250.000. Edisi desember 2011. Balai Besar Penelitian dan Pengembangan Sumberdaya Lahan Pertanian. Badan Penelitian dan Pengembangan Pertanian Kementrian Pertanian. 30 hal. 
Sharma, S., Vijay Kumar, dan Ram Babu Tripathi. 2011. Isolation of Phosphate Solubilizing Microorganism (PSMs) from Soil. J. Microbiol Biotech Res. 1 (2). Pp 90-95.

Sharma, Seema B., Riyaz Z Sayyed, Mrugesh H.T., dan Thivakaran A. Gobi. 2013. Phosphate Solubilizing Microbes: Sustainable Approach for Managing Phosphorus Deficiency in Agricultural Soils. A Springer Open Journal. Springer Plus. 2013,2:587 doi:10.1186/2193-1801-2-587. http://springerplus.com/content/2/1/587

Singh, S.K. dan Reddy K.R. 2011. Regulation of Photosynthesis, Fluorescence, Stomatal Conductance and Water-Use Efficiency of Cowpea (Vigna unguiculata [L.] Walp.) under drought, Journal of Photochemistry and Photobiology B:Biology, 105:40-50.

Suriadikarta, R.D.M dan D.A Simanungkalit. 2006. Pupuk Organik dan Pupuk Hayati. Balai Besar Litbang Sumberdaya Lahan
Pertanian Badan Penelitian dan Pengembangan Pertanian. Bogor.

Soewandita, H. 2003. Pemulihan Hara N, P dan $K$ pada Tanah Terdegradasi dengan Penambahan Amelioran Organik (Kasus pada Latosol Coklat Kemerahan di Sukabumi). Jurnal Sains dan Teknologi BPPT. http://www.iptek.net.id. [07-02-200].

Vessey, J.K. dan Heisinger, K.G. 2001. Effect of Penicillium bilaii Inoculation and Phosphorus Fertilization on Roor and Shoot Parameters of Field Grownpea. Can.J. Plant Sci. 81:363-366.

Zaidi A, Khan M.S., M. Ahemad, M. Oves, dan P.A. Wani. 2009. Recent Advances in Plant Growth Promotion by PhosphateSolubilizing Microbes. In: Khan MS (ed) Microbial Strategies for Crop Improvement, Berlin Heidelberg: Springer-Verlag. pp 2350. 